\title{
Intellectual Property Rights (IPR) Disputes in Cyberspace: U.S. Hegemony and Chinese Resistance
}

\author{
Dexin $\operatorname{Tian}^{1} \&$ Chin-Chung Chao ${ }^{2}$ \\ ${ }^{1}$ Professor of Liberal Arts, SCAD-Hong Kong, China \\ ${ }^{2}$ Assistant Professor, School of Communication, University of Nebraska at Omaha, USA \\ Correspondence: Dexin Tian, Ph. D., Professor of Liberal Arts, SCAD-Hong Kong, China. Tel: 852-2253-8023. \\ Fax: (852) 2253-8067. E-mail:dtian@scad.edu
}

Received: December 2, 2011

Accepted: February 7, 2012

Online Published: April 25, 2012

Doi:10.5539/jpl.v5n2p1

URL: http://dx.doi.org/10.5539/jpl.v5n2p1

\begin{abstract}
This paper aims at explicating the hegemonic pressure from the U.S. side and the constant resistance from the Chinese side during the U.S.-China IPR disputes in the cyberspace. The theory of hegemony and extended literature review reveal that during the U.S.-China IPR disputes in cyberspace, the dominant U.S. power has shaped the IPR world order so effectively for its own interests that China as a disadvantaged country has been included, albeit with reservations, in the broad consent of the U.S. hegemonic sphere of influence. This study has also demonstrated significant theoretical and practical implications.
\end{abstract}

Keywords: IPR disputes in cyberspace, U.S. hegemony, Chinese resistance

\section{Introduction}

To end his paper entitled “The Escalating Copyright Wars," Yu (2004) cited the following imaginary conversation between two people using maritime radios:

Speaker One: Please divert your course 15 degrees to the north to avoid a collision, over.

Speaker Two: Recommend you divert YOUR course 15 degrees, over.

Speaker One: This is the captain of a U.S. Navy ship. I say again, divert your course, over.

Speaker Two: No, I say again, divert YOUR course, over.

Speaker One: This is an aircraft carrier of the U.S. Navy. We are a large warship. Divert your course now! Over.

Speaker Two: This is a lighthouse, your call. (p. 949)

The above conversation vividly depicts the belligerent tone of the U.S. IPR administration agencies such as the United States Trade Representative (USTR), U.S. Department of Commerce, U.S. Government Intellectual Property Resources, and Inter Governmental Intellectual Property Resources over IPR disputes with their trade partners like China. During the past decades, the United States "has been aggressive in pushing for a universal intellectual property regime” (Shao, 2006, p. 4). Annually, the USTR collects and reviews the adequacy and effectiveness of the U.S. IPR protection in almost 100 countries all over the world. By identifying those countries infringing upon its IPR and taking necessary retaliatory measures against them, the United States intends to protect its economic interests by safeguarding the IPR of its nationals in the rest of the world. For instance, the USTR (2010) still put China on the top of its priority watch list in its Special 301 Report because "the overall level of IPR theft in China remains unacceptable” (p.19). In accordance with the Omnibus Trade and Competitiveness Act in 1988, the U.S. Congress established the Special 301 process, which mandated that the USTR submit to the Congress an annual report on unfair trade practices in foreign countries pursuant to Section 301 provisions of the Trade Act of 1974. In the Special 301 reports during the past decades, the United States kept showing its concern over China's policies that could unfairly harm the U.S. IPR holders and other measures that would severely restrict market access for U.S. IP products.

According to the Congressional Research Service (2010), over the past three decades, total U.S.- China trade rose from \$5 billion in 1980 to \$409 billion in 2008. As the second-largest U.S. trading partner, third-largest export market, and its biggest source, China is a huge market for U.S. exporters and investors. Thus, China’s 
protection of the U.S. IPR has attracted increasing concern and efforts from the USTR and its represented IPR businesses and associations like the International Intellectual Rights Alliance, Business Software Alliance, Association of American Publishers, and Motion Picture Association of America.

Generally speaking, IPR comprises three dimensions of patents, copyright, and trademarks. Over the years, the United States has been accusing China of both infringing on imported U.S. IPR products and exporting counterfeit IPR products through the U.S. customs. For example, the 2010 USTR 301 Special Report (2010) announced that the share of IPR-infringing products of Chinese origin seized at the U.S. border was $79 \%$ while the U.S. copyright industries reported severe losses due to piracy in China in 2009. Even the most recent USTR 301 Special Report (2011) still claimed that, "piracy over the Internet is a significant concern with respect to a number of trading partners including China.... Unauthorized retransmission of live sports telecasts over the Internet continues to be a growing problem for many trading partners, particularly in China” (p. 11). Due to such extremely rampant IPR infringement in China, there have been recurring U.S.-China IPR disputes and negotiations with apparent hegemonic pressure from the U.S. side and the constant resistance from the Chinese side during the past three decades not only on the ground but in the cyberspace as well. As sufficient ink has been spilled on the U.S.-China IPR disputes on the ground or in general (Berrell \& Wrathall, 2007; Lehman, 2006; Liao, 2006; Mertha, 2001; Montgomery \& Fitzgerald, 2006; Ross, 1996, Xue, 2005; Yu, 2005), the present study will just address the IPR disputes in the cyberspace between the United States as the biggest developed country and China as the largest developing country in the world.

Cyberspace is a term originally coined by science fiction writer William Gibson to describe data matrices existing in a dark distant future. Cotton and Oliver (1994) quoted Gibson's definition of cyberspace as "a consensual hallucination experienced daily by billions of legitimate opeators, in every nation, by children being taught mathematical conetpts... a graphic representation of data abstracted from the banks of every computer in the human system" (p. 54). As a common lexicon today, cyberspace "has come to mean the information spaces created by the technology of digital networked computer systems, most of which ulitmately connect with the mother of all networks, the Internet” (Chon, p. 1). In recent years, China's technological brekthroughs via various tactics and strategies already threaten U.S. command of the global commons, including cyberspace. Just as Schroeter, Sollenberger, and Verink (2010) noted, "by converting sea, air, space, and cyberspace into 'contested zones' for the US military, China undermines the existing basis of U.S. influence in East Asia and possibly, U.S. hegemony” (p. 2).

According to Bryant (2001), there are two dimensions of cyberspace. The first one is a 3-D cyberspatial environment which human beings can enter, move through, and interact with both the computer and other human beings. The other is the utilitarian world of networks of computers linked via cables and routers, which enable human beings to communicate, store, and retrieve information. They are both manifested on the Internet (pp. 139-140). The Internet, as Sardar (1996) remarked, "has been managed by the [U.S.] government-funded National Science Foundation (NSF).... The many networks that make the Internet, the network of all computer networks, are interlinked in a rough hierarchy [where] the big multinational corporations will dominate cyberspace” (p. 738). In Sardar's opinion, while government-funded network providers may offer the public free access, commercial providers are exploiting the Internet to the full to make profits by dictating and shaping cyberpolicies (p. 738).

To elucidate the main features of the U.S. hegemony and Chinese resistance as observed in the cyberspace, we will adopt the research method of historical analysis based on an extended literature review. As Zhao (2005) pointed out, historical analysis will illuminate on how our present has come about by providing us with a sense of the past while scholarly research findings may help uncovering those significant features, which might be hidden from view. As part of a bigger project, the present paper consists of the above background introduction and the following two parts of the theoretical framework and the extended literature review with the intention to enrich the extant relevant body of knowledge.

\section{Theoretical Framework}

Regarding China as a total alien to IPR, the United States has been playing a missionary role to indoctrinate the Chinese with the present U.S. IPR perspectives, which represent the interests of the dominant U.S. IPR industries. Scholars (Halbert, 2005; Hartley \& Montgomery, 2009; Liao, 2006; Shao, 2006; Xue, 2005) share the idea that it is for the purpose of expanding its economic interests and global power that the United States has been pressing China to substantively revise its patent, copyright, trademark laws and other IPR systems and repeatedly restructure its IPR enforcement mechanisms. For example, to guarantee "the global market dominance of Hollywood, Tin Pan Alley and other U.S.-based IPR industries, the United States has been taking an 
American-led 'winner-takes-all' approach through international agencies like the Agreement on Trade-Related Aspects of Intellectual Property Rights (TRIPS)” (Hartley \& Montgomery, 2009, p. 4). As one of the specific agreements annexed to the World Trade Organization (WTO) Agreement, all incoming members of the WTO must commit themselves to observing the standards of TRIPS. In order to obtain U.S. agreement on its WTO application, China "was forced to make numerous concessions" (Liao, 2006, p. 208).

However, China has been strategically cooperative and tactically resistant. For instance, under the international pressure, especially that from the United States, and to fulfill its commitment as a member of the WTO since December 11, 2001, China has established all the necessary agencies and required legal regulations for better protection of IPR. Yet, the enforcement of these legal regulations by these agencies has never been satisfactory to the international community and, especially, the IPR-related industries. Moreover, U.S. companies like Cisco, Microsoft, Yahoo, and Google have to make compromises and observe Chinese information censorship laws so as to stay put or aim for business expansions in China. The recent departure and return of Google best illustrates the features of the Chinese market. Since this study focuses on the IPR disputes between China and the United States on the Internet, it is appropriate to examine the U.S. hegemonic pressure and the Chinese constant resistance during their IPR disputes in the cyberspace through the theoretical lens of the theory of hegemony.

Hegemony as a concept refers to "political leadership based on the consent of the led, a consent which is secured by the diffusion and popularization of the world view of the ruling class" (Bates, 1975, p. 352). In international relations, hegemony is used to "connote the predominant position of the most powerful state in the international system or the dominant state in a particular given region" (Faiz, 2007, p. 1). The modern usage of hegemony as a concept comes from the Italian Marxist and social theorist, Antonio Gramsci. In his Selections from the Prison Notebooks, Gramsci (1971) posited that a dominant party, in hegemonic conditions, can "exercise a balancing and arbitrating function between the interests of their group and those of other groups, and succeed in securing the development of the group which they represent with the consent and assistance of the allied groups” (p. 148). To Gramsci, hegemony is the process by which the dominant classes propagate their values and ideology via social institutions such as mass media, religious organizations, schools and the family. The dominant values and ideology are so ingrained in people's minds that they not only limit people's vision but also enable it (Raphael, 2003, p. 2).

While drawing upon Gramsci’s notion of hegemony, Robert Cox (1981) was trying to put his thought of hegemony in the global context. To Cox, successive dominant powers in the international system have shaped a world order that suits their interests as a result of their coercive capabilities and broad consent even among those disadvantaged. Cox regarded the United States as a dominant power in the international system, which has successfully globalized its hegemonic ideas all over the world including China. To spell out the changes in the world order, Cox proposed his idea of the "frame of action," which comprises ideas, material capabilities, and institutionalization. Ideas are those shared notions or thought patterns of the nature of social relations and those of collective images of social order held by different groups of people. As the ideas are historically conditioned, they can predict behaviors when conflicts arise between states such as negotiation, confrontation, or war. Material capabilities refer to material conditions composed of technological and organizational capabilities and natural resources, which can be productive and destructive potentials. Institutionalization is a means of stabilizing and perpetuating a particular order through human institutions. Such institutions reflect the power relations and the collective images that are consistent with these power relations (pp. 131-137).

Having discussed the theoretical framework, we will review the relevant literature on the U.S.-China IPR disputes in the cyberspace. Specifically, we will critically analyze the existing scholarship according to the following three categories.

\section{Extended Literature Review}

\subsection{U.S.-China Cyberspace IPR Disputes}

As cyberspace is a kind of technology, it is necessary to conceptualize technology before defining cyberspace. The word "technology" originates from a Greek word meaning to understand, to belong to, or to be in command of something. Gregory (1998) viewed modern technology as "something human, invented, realized, steered and secured by humans for humans" (p. 133). Similary, Bijker (2006) regarded technology as "the most consequential cultural practice that humankind has developed” (p. 2). Slack and Wise (2005) further explained, "technology is, at least in terms of its most popular usage, a constructed and useful thing" (p. 95). By conceptualizing technology in terms of its "thingness," Slack and Wise intended to emphasize the "discrete boundaries" between technologies and other objects (p. 96). To put technology into the legal and political contexts, Slack and Wise elaborated on Rybczynski's idea about technologies, which refer to "ways of building 
order in our world” (p. 175). Just as Boyd-Barrett (2006) noted, networking technologies, which were developed by the U.S. defense and government agencies, possessed equipment monopoly and had dramatic consequences for technology integration, innovation, and network commercialization. Thus, practical as it is, technology is also socially constructed by human beings to represent their values and serve their wills.

Against such technological background, it will be easy to talk about the U.S.-China IPR disputes in the cyberspace. Under the Special 301 provisions of the U.S. Trade Act of 1974, the USTR has been put in charge of identifying foreign countries that deny adequate and effective protection of U.S. IPR and fair and equitable market access for U.S. persons that rely on IPR protection. As the Executive Office of the U.S. President, the Office of the USTR is headed by the U.S. Trade Representative who is a Cabinet member at the ambassador level and serves as the president's principal trade advisor, negotiator, and spokesperson on trade issues (Mission of the USTR, p. 1). Through an institutionalized network composed of the American embassies and consulates, the Central Intelligence Agency, and IPR associations, the USTR obtains its information concerning the protection of the U.S. IPR and market access for U.S. nationals depending on IPR products in foreign countries. China has been identified, investigated, and put on the USTR Priority Foreign Country list for the past decade. For instance, the USTR Special 301 decisions on China for the past ten years can be seen from Table 1.

Table 1. USTR Special 301 Decisions on China

\begin{tabular}{|c|c|c|c|}
\hline Year & Decisions & Year & Decisions \\
\hline 1989 & Priority Watch List & 1999 & Section 306 Monitoring \\
\hline 1990 & Priority Watch List & 2000 & Section 306 Monitoring \\
\hline 1991 & $\begin{array}{l}\text { Priority Foreign } \\
\text { Country }\end{array}$ & 2001 & Section 306 Monitoring \\
\hline 1992 & Not on the list & 2002 & Section 306 Monitoring \\
\hline 1993 & Priority Watch List & 2003 & Section 306 Monitoring \\
\hline 1994 & $\begin{array}{l}\text { Priority Foreign } \\
\text { Country }\end{array}$ & 2004 & Section 306 Monitoring \\
\hline 1995 & Not on the list & 2005 & Priority Watch List; Section 306 Monitoring \\
\hline 1996 & $\begin{array}{l}\text { Priority Foreign } \\
\text { Country }\end{array}$ & 2006 & $\begin{array}{l}\text { Priority Watch List; Section } 306 \text { Monitoring; } \\
\text { Considering WTO Dispute Settlement }\end{array}$ \\
\hline 1997 & $\begin{array}{l}\text { Section } 306 \\
\text { Monitoring }\end{array}$ & 2007 & $\begin{array}{l}\text { Priority Watch List; Section } 306 \text { Monitoring; } \\
\text { Pursuing WTO Dispute Settlement }\end{array}$ \\
\hline 1998 & $\begin{array}{l}\text { Section } 306 \\
\text { Monitoring }\end{array}$ & 2008 & Priority Watch List \\
\hline
\end{tabular}

Source: USTR Special 301 Reports, 1989-2008

As can be seen from Table 1, China has been put on the Priority Watch List, Section 306 Monitoring, Priority Foreign Country, and WTO Dispute Settlement Pursuit almost every year from 1989 to 2008. Watch List nations have particular problems with respect to IPR protection, enforcement, or market access for U.S. individuals or businesses relying on intellectual property. The Priority Watch List singles out those countries, which have the same problems as those on the Watch List but are the focus of increased bilateral attention concerning the problem areas. Under Section 306 of the U.S. legal act, the USTR monitors a country's compliance with bilateral intellectual property agreements. If the country fails to satisfactorily implement an agreement, the USTR may apply trade sanctions. Priority Foreign Country refers to a foreign country that has the most onerous acts, policies, or practices that deny adequate and effective IPR and fair and equitable market access to the U.S. nationals relying upon IP protection (USTR Special 301 Report, 2006, p. 15).

With regard to the cyberspace IPR disputes, the USTR “devoted special attention to the growing issue of Internet piracy” in 2002 and China was put under Section 306 in that year's Special 301 Report, which means that the USTR monitored China's compliance with bilateral intellectual property agreements and would apply trade sanctions if China did not satisfactorily implement the bilateral agreement (USTR Special 301 Report, 2002, pp. 1-16). Even in its most recent Special 301 report, the USTR (2011) once again publicized: 
Piracy over the Internet in China continues to be a source of concern and injury to the copyright industries and the United States. It is estimated that there are 457 million Internet users in China, as compared with 223 million in the United States; when coupled with reports that $99 \%$ of all music downloads in China are illegal, the concerns of industry are understandable. (p. 20)

Thus, we can have a glimpse of the severity of China's IPR infringement issues in cyberspace. To the United States, strong actions to curb copyright piracy on the Internet are critical to the future of IPR enforcement in China. One reason the Chinese government has offered for this situation is that "it lacks the knowledge and the necessary skills to combat piracy alone" (Hollingsworth, 2004, p. 45). However, the United States "escalated its wars with China in the 1990s by non-renewal of Most Favored Nation status, opposition to entry into WTO, and most seriously, trade sanctions of repeated threat of billions of import tariffs" (Shao, 2006, p. 5). Under the pressure of the US Special 301 investigations, which have become "China's unshakable nightmare" (Xue, 2005, p. 295), China has been strategically cooperative but tactically resistant. Just as Shao (2006) noted, "the United States has forced China to produce a high level of IPR regime while in practice China is reluctant to fully enforce these laws for fear that they may stifle its own energy of creativity” (p. 1). In fact, during the recurring U.S.-China IPR disputes, the United States has been imposing hegemonic pressure upon China by using both the domestic Special 301 promissions and the WTO IPR dispute system.

\subsection{The U.S. Hegemonic Pressure}

Since the beginning of the commercial activities in cyberspace, Ibanez (2008) contended, "some American corporations have been in a priviledged position to control the structures of power and to determine what users and consumers can and cannot do" (p. 142). With regard to the relationship between knowledge and power, Foucault (1977) remarked, "power and knowledge directly imply one another; there is no power relation without the correlative constitution of a field of knowledge, nor any knowledge that does not presuppose and constitute at the same time power relations” (p. 27). As for the relationship between knowledge and power in cyberspace, Sardar (1996) pointed out, the Internet came into being with the U.S. National Science Foundation (NSF) as the sponsor, and the NSF has now handed over the managerial control of the Internet to three commercial carriers of Sprint, Ameritech, and Pacific Bell, which "will become the principal providers of access to the Internet" (p. 738).

In his article entitled "Who Will Control the Internet?" Cukier (2005) described that the United States responded to those foreign governments, which asked to transfer the Internet control from the American Non-Governmental Organizations (NGOs), with a new Monroe Doctrine meaning that other powers should not interfere with the affairs of the United States. Cukier also broke the cyberspace myth that the Internet is totally decentralized and inherently uncontrollable. He pointed out that oversight and coordination are needed in four critical areas to operate the Internet smoothly. First, somebody must decide how to manage the domain names ending with suffixes such as “.com” and ".net” as well as two-letter country code suffixes like “.cn” for China. Second, some one needs to allocate the limited Internet Protocol numbers. Third, somebody must make sure that the root servers operate the domain name system properly. Among the 13 root servers in the entire world, 10 are operated from the United States. Finally, some one needs to set the technical standards that guarantee the development of the Internet. Thus, the Internet network requires some centralized control to make it function properly. Such centralized control comes from a nonprofit organization called "the Internet Corporation for Assigned Names and Numbers (ICANN), which was set up by the United States in 1998... [as] an instrument of American hegemony over cyberspace" (Cukier, 2005, pp. 1-2).

From the above, we find that it is the United States that supervises over the Internet infrastructure of the domain names, protocol numbers, root servers, and technical standards. Such Internet governance is closely related to mainstream policy-making and value judgments. Just as Cukier (2005) summarized, "the Internet, before it is physically constructed from routers and cables, is made up of values” (p. 2). Boyd-Barrett (2006) also remarked, "the US was the undisputed global information and communication leader," and that "US 'global primacy' rested on its ability to develop new technologies and industries faster" (pp. 59-61). In the following section, we can discuss how the U.S. hegemonic power is influencing China in its cyberspace IPR protection and what resistance has been witnessed during the process.

\subsection{The Chinese Resistance to the U.S. Hegemonic Pressure}

Most Chinese are familiar with the popular Maoist slogan, which goes where there is pressure, there is resistance. The phenomenon of U.S. pressure and Chinese resistance in cyberspace can be demonstrated in the following three aspects. First, according to Xue (2005), a product of the 1992 U.S.-China Memorandum of Understanding is the International Copyright Treaties Implementing Rules, which "grant foreign works a higher level of 
copyright protection than Chinese works” (p. 303). When China was revising its copyright law in 2001, the pressure from the United States was to "bring China's copyright law in line with the TRIPS Agreement and the network age...featuring the U.S. Digital Millennium Copyright Act (DMCA).” However, China showed its resistance by aiming at "eliminating the double standards in the Chinese copyright system" (p. 304) so that both Chinese and foreign works either in the traditional expressions of hard copies or electronic versions in cyberspace enjoy the same kind of copyright protection.

Besides, Taylor (1997) also noted, the USTR investigation in a Section 301 violation case is supposed to proceed in parallel with the WTO dispute settlement process, but the United States still unilaterally awards itself the right to take retaliatory actions against countries even if they are complying with the minimum standards of TRIPS. Thus, although the United States "has forced China to produce a high level of IPR regime while in practice China is reluctant to fully enforce these laws for fear that they may stifle its own energy of creativity" (Shao, 2006, p. 1).

Second, by integrating China into WTO, the United States managed to make China sign the TRIPS Agreement, which requires each WTO member country to harmonize its intellectual property laws with the minimum standards elaborated in the agreement including:

1) To propertize some classes of information (e.g. computer software, online services, and plant varieties) that had previously not been commodified;

2) To raise the price of information by increasing the duration of protection to twenty years; and

3) To play a greater role in enforcing the property rights of multinational firms operating on global information infrastructure. (Sum, 2003, p. 378)

Nevertheless, these minimum standards are "generally those already existing throughout the United States, Europe, Australia, and Japan” (Halbert, 2005, p. 2). Although countries in the developing countries like China expressed enormous disagreement regarding the inclusion of TRIPS into the WTO framework, they did not have "the negotiating power to withstand the US position" (p. 2). This is why it took nearly 10 years for China to negotiate with the United States over its entry into WTO.

Since joining the WTO on December 11, 2001, China has strengthened its legal framework and amended its IPR laws and regulations in compliance with the WTO Agreement on TRIPS. Besides, China has been shaping its IPR practice with its own characteristics by pursuing the strategy with one base, two goals, and three principles. The one base of China's IPR system is to respect and reasonably protect IPR. The two goals are: China's IPR regime will first benefit the transmission of knowledge and second facilitate human beings to share the welfare of knowledge accumulation. The three principles are: first, China's IPR system will be in line with the status quo; second, the public interests will take precedence over private rights; and third, national interests will take priority over private ones (Shao, 2006, p. 6). In the case of cyberspace management, there have been three constant tenets of China's approach: First, the state will retain ownership and control of the main infrastructure of backbone networks. Second, the ownership and control of access provider services will remain in Chinese hands. Third, on-line information and activities must conform to Chinese Communist Party restrictions (Hartford, 2000).

From the above, we can see that China has been emphasizing the functions of creative works for the benefits of the society and the interests of the community. The immature IPR system in the past and the strategy of one base, two goals, and three principles today both aim at transmitting information and sharing knowledge, in which individual interests of creators or authors usually give way to those of the group. The spirit of the cyberspace tenets also clarifies the collective ownership and control of the Internet access, and the content and activities in the cyberspace will be conducted in line with the rules of the Party and the State. In addition, since January 2000, the Chinese government promoted a series of self-regulations among Internet content providers and individual users, which serve as an effective catchall mechanism of Internet communication management. Any Internet companies, which intend to do business in the Chinese market, have to accept these self-censorship regulations and assist the Chinese government prohibiting online transmission of state secrets, including any online materials that might subvert state power, disturb social order, undermine reunification efforts with Taiwan, preach the teachings of evil cults, infringe upon national customs and habits, and harm the honor of the People's Republic of China (Liang, 2001).

Finally, regardless of its WTO membership, China has not been genuinely enforcing its IPR laws and regulations on the one hand, which might prevent its citizens from making use of others' IPR freely. On the other hand, censorship is built into all layers of China's Internet infrastructure known as the "Great Firewall of China." With 
this firewall, the Chinese government managed to regulate both domestic and international online media to function within its approved parameter of the marketplace. For instance, facing the dilemma of either holding to the business ethics of committing to free speech or entering the Chinese market by observing the Chinese cyberspace laws and regulations, four U.S. Internet companies - Google, Yahoo, Cisco, and Microsoft — all compromised their principles and kowtowed to the technological and political demands of the Chinese government. According to Lee (2010), Google admitted that it had agreed to purge any websites and messages considered sensitive by the Chinese government. The search engines of Microsoft and Yahoo agreed to urge their users to use real names for registration. These companies were actually assisting the Chinese government filtering and even self-censoring words like "human rights," "democracy," or "Chinese torture." Criticized as the "Gang of Four," these four companies were summoned by the U.S. Congress in 2006 to account for why they were helping the Chinese government to police the Internet, making it all the more difficult for the Chinese netizens to enjoy their freedom to access information. Unable to tolerate the Chinese cyber attacks and forced self-censorship of its online communication, Google left China on March 22, 2010 and won world-wide applause. However, facing its loss of $\$ 500$ million or over $2 \%$ of its annual revenue, Google's return to the Chinese market remains uncertain but counted.

\section{Conclusion}

The purpose of this study was to explicate the hegemonic pressure from the U.S. side and the constant resistance from the Chinese side during the U.S.-China IPR disputes in the cyberspace. Under the theoretical framework of the theory of hegemony, we have conducted a critical and historical analysis of the relevant literature and found the following. Although there has been resistance from the the Chinese side in the U.S.-China IPR disputes in cyberspace, the dominant U.S. power has shaped the IPR world order so effectively to suit its interests that China as a disadvantaged country in the international system has been included in the broad consent of the U.S. hegemonic sphere of influence. Nevertheless, the essence of the hegemony theory is that the dominant power maintains its rule in the international system via broad consent even among those who are disadvantaged. As a disadvantaged country in the U.S.-dominated IPR world order, China has given its consent with constant and strong reservations by strategically cooperating with the United States in some areas and tactically opposing the United States in other areas during the U.S.-China IPR disputes. Thus, the present study has revealed its theoretical implication to advance the theory of hegemony by redefining the key term consent as consent with reservations or strategic consent and tactical resistance.

Practically, it is a well-known fact that, for over three decades, the U.S.-China IPR disputes have been going on with very little commendable achievements in terms of heavy losses of the U.S. annual revenue in the IPR industries and rampant copyright piracy rate in all copyright sectors in China. While the United States has been culturally insensitive and habitually belligerent, China has been strategically cooperative and tactically resistant. It is worth mentioning here that, in his 2012 State of Union Address, President Obama still made public: "Tonight, I'm announcing the creation of a Trade Enforcement Unit that will be charged with investigating unfair trade practices in countries like China” (President Obama’s State of Union Address, 2012). Probably, this “Trade Enforcement Unit" is created to replace the USTR, which has proved itself incapable in dealing with other trade partners such as China due to playing "a missionary role to indoctrinate the Chinese with the present U.S. IPR perspectives with obvious moral superiority” (Shao, 2006, p. 1). Against this backdrop, we believe that our study is timely to waken up many Chinese and American officials to the real nature of the recurring U.S.-China IPR disputes, especially in the cyberspace today. Hopefully, the present study will also enhance mutual efforts from both countries and facilitate genuine communication between the two sides with different cultural backgrounds in their decade-long cyberspace IPR disputes.

\section{References}

Bates, T. R. (1975). Gramsci and the theory of hegemony. Journal of the History of Ideas, 36(2), 351-366. http://dx.doi.org/10.2307/2708933

Berrell, M., \& Wrathall, J. (2007). Between Chinese culture and the rule of law. Management Research News, 30(1), 57-76. http://dx.doi.org/10.1108/01409170710724304

Bijker, W.E. (2006). The vulnerability of technological culture. Culture of Technology and the Quest for Innovation. H. Nowotny. New York, Berghahn Books.

Boyd-Barrett, O. (2006). Cyberspace, globalization and US empire. In O. Boyd-Barrett, (Ed.), Communication media globalization and empire. Eastleigh, UK: John Libbey Publishing.

Bryant, R. (2001). What kind of space is cyberspace? Minerva-An Internet Journal of Philosophy, 5, 138-155. 
http://dx.doi.org/ 10.1177/0165551506070716

Chon, M. (n.d.). Introduction to cyberspace and the law. Retrieved from http://www.cyberspacelaw.org/chon/index.html (May 7, 2007)

Congressional Research Service. (2010). China-U.S. Trade Issues. Retrieved from www.fas.org/sgp/crs/row/RL33536.pdf (March 8, 2010)

Cotton, B., \& Oliver, R. (1994). Cyberspace: The new world game. The Cyberspace Lexicon. London, Phaidon.

Cox, R. (1981). Social forces, state and world orders: Beyond international relations theory. Millennium, 10(2), 126-155. http://dx.doi.org/10.1177/03058298810100020501

Cukier, K. N. (2005). Who will control the Internet? Foreign Affairs, 11/12, 1-5. http://dx.doi.org/10.2307/20031772

Faiz, P. M. (2007). Marxist theory of hegemony. Journal Hukum 1, 1-10.

Foucault, M. (1977). Discipline and punish: The birth of the prison (Translated from French by Alan Sheridan). New York, NY: Random House.

Gramsci, A. (1971). Selections from the prison notebooks. London: Lawrence and Wishart.

Gregory, W. T. (1998). Traditional language and technological language. Journal of Philosophical Research, 23, 129-145

Halbert, D. (2005). Globalized resistance to intellectual property. Retrieved from http://globalizaton.icaap.org/content/v5.2/halbert.html (April 24, 2007)

Hartley, J. \& Montgomery, L. (2009). Creative industries come to China. Chinese Journal of Communication, 2(1), 1-12. http://dx.doi.org/10.1080/17544750802638798

Hollingsworth, H. (2004). The quest for thought protection: China's intellectual property rights' environment regime to improve with increased education to the public. Business Law Brief, Spring, 45-51.

Ibanez, J. (2008). Who governs the Internet? The emerging regime of e-commerce. In J. Graz and A. Nolke (Eds.), Transnational private governance and its limits. New York, NY: Routledge.

Lee, M. (2010). Revisiting the "Google in China" question from a political economic perspective. China Media Research, 6(2), 15-24.

Lehman, J. A. (2006). Intellectual property rights and Chinese tradition section: Philosophical foundation. Journal of Business Ethics, 69(1), 1-9. http://dx.doi.org/10.1007/s10551-006-9059-8

Liang, C. (2001). Red light, green light: Has China achieved its goals through the 2000 Internet regulations? Vanderbilt Journal of Transnational Law, 34, 1417-1442.

Liao, J. C. (2006). China's response to the global IPR regime: Compliance or resistance? Issues and Studies, 42(4), 175-222.

Mertha, A. C. (2001). Pirates, politics, and trade policy: Structuring the negotiations and enforcing the outcomes of the Sino-US intellectual property dialogue, 1991-1999. Unpublished doctoral dissertation. University of Michigan, Dearborn.

Mission of the USTR. (n.d.). Retrieved from http://www.theUSTR.gov/Who_We_Are/Mission_of_the _THE USTR.html (April 24, 2007)

Montgomery, L., \& Fitzgerald, B. (2006). Copyright and the creative industries in China. International Journal of Cultural Studies, 9(3), 407-418. http://dx.doi.org/10.1177\%2F1367877906066886

President Obama's State of Union Address. (2012). Retrieved from http://www.forbes.com/sites/jeremybogaisky/2012/01/24/full-text-president-obamas-state-of-the-union-addr ess/2/ (Jan. 26, 2012)

Raphael, C. (2003). Theory of hegemony and ideology. Retrieved from http://codesign.scu.edu/chad/120/heg.html (March 17, 2007)

Ross, R. S. (1996). Enter the dragon. Foreign Policy, 104, 18-25. http://dx.doi.org/10.2307/1148987

Sardar, Z. (1996). Cyberspace as the darker side of the west. In Z. Sardar, \& J. Ravetz (Eds.), Cybercultures: Culture and politics on the information superhighway. London, Pluto.

Schroeter, T., Sollenberger, M., \& Verink, B. (2010). Challenging US command of the commons: Evolving 
Chinese defense technologies as a threat to American hegemony? Bologna Center Journal of International Affairs, 13, 1-16.

Shao, K. (2006). What may validate intellectual property in the traditional Chinese mind? Examining the U.S.-China IP disputes through a historical inquiry. Journal of Information, Law \& Technology, 1, 1-22.

Slack, J. D., \& Wise, J. M. (2005). Culture + technology: A primer. New York, NY: Peter Lang Publishing, Inc.

Sum, N. L. (2003). Informational capitalism and U.S. economic hegemony: Resistance and adaptations in East Asia. Critical Asian Studies, 35(3), 373-398. http://dx.doi.org/10.1080/1467271032000109890

Taylor, C. O. (1997). The limits of economic power: Section 301 and the World Trade Organization dispute settlement system. Vanderbilt Journal of Transnational Law, 30, 1-6.

$\begin{array}{lllll}\text { USTR } & \text { special } & 301 & \text { report } & \text { (2001). }\end{array}$ http://hongkong.usconsulate.gov/uploads/images/J6EH6KGM-c0kwdU0CSnXhA/usinfo_301_00-special.p df. (June 26, 2009)

$\begin{array}{lllll}\text { USTR } & \text { special } & 301 & \text { report } & \text { (2003). }\end{array}$ http://www.ustr.gov/Document_Library/Reports_Publications/2003/2003_Special_301_Report/Section_Ind ex.html (June 26, 2009)

USTR special 301 report. (2000). Retrieved from http://usinfo.state.gov/ei/Archive/2003/Dec/31-708465.html (April 18, 2009)

$\begin{array}{lllll}\text { USTR } & \text { special } & 301 & \text { report. } & \text { (2002). }\end{array}$ http://www.theUSTR.gov/assets/Document_Library/Reports_Publications/2002/2002_Special_301_Review /asset_upload_file567_6367.pdf

USTR special 301 report. (2006). Retrieved from http://www.the USTR.gov/assets/Document_Library/Reports_Publications/2006/2006_Special_301_Rev iew/asset_upload_file473_9336.pdf

USTR $\quad$ special $301 \quad$ Report. $\quad$ (2005). $\quad$ Retrieved from http://www.theUSTR.gov/assets/Document_Library/Reports_Publications/2005/2005_Special_301_Review /asset_upload_file195_7636.pdf (March 23, 2007)

$\begin{array}{lllll}\text { USTR } & \text { special } & 301 & \text { report. } & \text { (2008). }\end{array}$ http://www.ustr.gov/Document_Library/Press_Releases/2008/April/SPECIAL_301_Report.html (June 26, 2009)

$\begin{array}{lllll}\text { USTR } & \text { special } & 301 & \text { report. } & \text { (2010). }\end{array}$ http://www.ustr.gov/about-us/press-office/reports-and-publications/2010-3 (Oct. 12, 2010)

USTR special $301 \quad$ report. (2011). Retrieved from http://www.ustr.gov/about-us/press-office/reports-and-publications/2011/2011-special-301-report(Jan. 26, 2012)

USTR. (2006). U.S.-China trade relations: Entering a new phase of greater accountability and enforcement. Retrieved from http://www.ustr.gov/assets/Document_Library/ReportsPublication/2006/asset_upload_file921_8938.pdf

Xue, H. (2005). Between the hammer and the block: China's intellectual property rights in the network age. University of Ottawa Law \& Technology Journal, 2(2), 291-314.

Yu, P. K. (2001). From pirates to partners: Protecting intellectual property in China in the twenty-first century. American University Law Review, 50, 131-243.

Yu, P. K. (2004). The escalating copyright wars. Hofstra Law Review, 32, 907-951. http://dx.doi.org/10.2139/ssrn.436693

Yu, P. K. (2005). Still dissatisfied after all these years: Intellectual property, post-WTO China, and the avoidable cycle of futility. Paper presented at the "U.S.-China Trade: Opportunities and Challenges" Conference at the University of Georgia School of Law. Retrieved from http://ssrn.com/abstract=578584

Zhao, J. Q. (2005). Communication and rural development in China: A historical review. Unpublished paper, 1-33. Retrieved from http://web.ebscohost.com/ehost/detail?vid=6\&hid=6\&sid=a5d0bebf-9a03-466e-ade8-23d7 (Oct. 12, 2009) 